\title{
Climate Change, COVID-19, and Global Systemic Change
}

\author{
Tanner C. Caterina-Knorr ${ }^{\mathrm{a}}$; Phoebe Everingham ${ }^{\mathrm{b} *}$

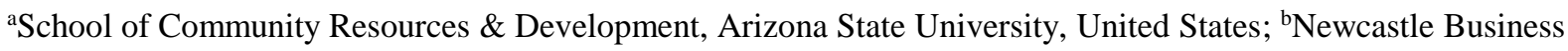 \\ School, University of Newcastle, Australia \\ *Correspondence: phoebe.everingham@newcastle.edu.au
}

Received 21 April 2021; Revised 26 June 2021; Accepted 11 July 2021

\begin{abstract}
Issues such as climate change, which are directly linked to global health pandemics such as COVID-19, demonstrate the urgent imperative to implement responsible tourism management. This viewpoint makes the case for developing responsible pathways forward - away from top-down economic growth models, towards centering the need for heightened environmental and socially sustainable and responsible practices. The pause on tourism from COVID-19 provides an opportunity for new pathways forward that consider the dire situation of the planet. Authors present the Future of Tourism Coalition's Guiding Principles as a practical model for tourism destinations to manage and develop tourism more holistically.
\end{abstract}

KEYWORDS: capitalism; climate change; COVID-19; economic growth; sustainability; tourism management

\section{Introduction}

In the inaugural issue of the Journal of Responsible Tourism Management, Cheer, Ting, and Leong (2021) make the case that a new era for tourism management has arrived. Tourism underpinned by endless growth has in many cases contributed to irreversible harm to ecosystems, and exacerbated widespread social inequities. It may well be that these continuous growth models pose existential threats to the survival of the tourism industry itself. Indeed, capitalist development and a culture that promotes endless consumption depends upon destructive environmental activities. Climate change and deforestation are exposing humans to increasingly more novel viruses, such as COVID-19. There is a growing body of evidence that connects human development and biodiversity loss to disease outbreaks that jump from animal to human (Vidal, 2020). Climate change is also contributing to this problem. Thawing permafrost in the Artic, for example, is emitting not only more carbon and methane emissions, but also ancient diseases, such as the plague (Fox-Skelly, 2017). In this context, there is no 'going back to normal'.

There is a need for responsible tourism models that are cognizant of these core problems and directly address the issues of capitalist growth and climate change. The ramifications of COVID-19, as 'the hidden cost of human economic development' (Jones et al., 2008, as cited in Vidal, 2020) are likely to "shape and influence invocations of responsible tourism 
henceforth" (Lew et al., 2020, as cited in Cheer et al., 2021, p. 3). While there are several important issues surrounding the tourism industry, this article addresses the two existential threats to the tourism industry, climate change and COVID-19, deemed as such by the United Nations Secretary General and the Center for Responsible Travel (CREST, 2020; UNSG, 2020). This article also outlines how these two core issues are associated with capitalist growth models, and considers several guiding principles that will be useful for underpinning the ways forward for responsible tourism.

\section{Tourism Embedded within the Economic Growth Paradigm}

Derived from nearly all modes of transportation connecting travelers with their destination, emissions from the tourism industry are significant contributors to the global issue driving climate change (Shakouri, Khoshnevis Yazdi, \& Ghorchebigi, 2017). By pushing economic outcomes, marked by Gross Domestic Product (GDP) and Gross National Income (GNI), and conflating the concepts of development and growth, policy-makers and institutions regard economic growth as a "panacea for a multitude of (often changing) socio-economic challenges" (Schmelzer, 2015, p. 264). Focusing only on economic returns in the context of neoliberalism, businesses, Destination Management/Marketing Organizations (DMOs), and politicians may have little incentive or agency to change the system (Dredge, 2019). It is clear that certain human activity has exceeded the planetary boundaries that would enable the tourism industry to produce more sustainable outcomes, requiring an urgent need for global systemic change (Cheer et al., 2021).

Prior to COVID-19, the tourism industry was already grappling with economically, socially, and environmentally unsustainable practices. Tourism dependency and an emphasis on tourism arrivals created the phenomenon of overtourism (Milano, Novelli, \& Cheer, 2019). Discounting assets and resources within the social and environmental pillars of sustainability while stressing economic gains is a hallmark of the economic growth paradigm. GDP and other economic indicators are used as exemplars of positive development through the concept of economic growth. However, couching economic growth indicators within development ideology largely causes the opposite of the desired outcomes, unless pro-poor strategies, such as partnerships with local communities, are fostered (Scheyvens, 2007). The issues with the tourism industry's dependency on growth have been increasingly revealed by the onset of COVID-19 and the dramatic decrease of international tourism arrivals.

Continual growth leads to inequities, injustices, and unsustainable practices within the tourism industry. As tourism is equated with economic drivers towards 'growth', it privileges foreign arrivals over holistic tourism development within tourism policies. Justifying the increased quantity of tourists for the purposes of economic growth largely dismisses the quality of social and environmental needs within the destination. Common pool resources, both natural and cultural, become depleted in exchange for monetary gains that tend to only benefit a minority of people. This is an inequitable and unsustainable cycle with unfavorable outcomes for local communities that largely do not have a voice in changing the system.

Further disrupting social and environmental sustainability is the convergence of industry and politics under neoliberalism. The use of public funds to finance private tourism infrastructure (Dredge, 2019) and loosening policies for private benefit has accelerated inequities within destinations (Higgins-Desbiolles et al., 2019). The rationale of allowing business to steward 
public assets is derived from the notion that private industry can better manage resources on behalf of the government and the people. This 'trickle down' model, however, disturbs the ability for the populous to have a say in how the resources are managed. The purpose of the corporation is to increase financial output; its loyalty is not to the majority of people or the environment, but profit for the privileged few. In both the Global North and Global South, tax incentives and privatization of tourism development has pivoted the representation and ownership of the Commons from the people to the corporation. While some degree of economic development is necessary within destinations, these gains must be mitigated by social and environmental concerns to ensure equitable distribution of resources.

\section{Sustainability and Climate Change}

Climate change is impacting delicate destinations where travelers visit and communities reside. From beaches in the Caribbean to the savannahs of East Africa, ecosystems are threatened by the changing climate and unsustainable environmental practices. There is a communal, business, and moral interest in preserving these resources for not only the tourism industry to enjoy, but for those working in the tourism industry. Without these resources that tourists come to visit, tourism labor markets will have to shift, leaving many unemployed. For example, many tourism destinations across the globe have shut down for indefinite periods of time due to the destruction of local ecosystems from overtourism. Maya Bay on the island of Phi Phi Leh, Thailand, made famous by the movie The Beach, received roughly 170 visitors per day in 2008. By 2017, that number had jumped to 3,500 per day; a case of overtourism that subsequently led to extreme environmental degradation and the closure of the site until 2021 (BBC, 2019). Overtourism has negative consequences for natural environments and local communities - and ironically the tourism operators themselves. Similarly, the impacts of climate change on natural environments will also detrimentally affect tourism operators.

In 2020, Australia experienced unprecedented wildfires that ravaged parts of the country in peak tourism season, with disastrous effects on businesses in these destinations. The following season saw floods, followed by mouse plagues, keeping tourists away from regional areas. With the effects of climate change increasingly impacting natural environments, tourism operators will need to rethink how their businesses can remain viable. Biodiversity is declining with far-reaching ramifications on the human species. Business as usual cannot continue if there is nothing left for tourists to come see. Often, these resources are taken for granted as consumable products with endless supply. However, these resources are finite and increasingly under threat due to the consequences of climate change (Epler Wood, 2017).

\section{Adaptation or Mitigation?}

There are two primary ways to combat climate change: adaptation and mitigation. Adaptation denotes accommodations for the impacts of climate change, such as raising or moving beachfront properties and adapting business models to climate catastrophes. Mitigation represents the ways in which the tourism industry's overall impacts can decrease, typified by tour operators shifting the means of transportation within destinations to lessen the carbon emissions. While small changes are currently being adopted, it is important to consider the wider trend of increased travel and its contribution to climate change. 
Airlines and cruise lines are not fuel efficient, nor do they currently run on renewable or clean energy. As the tourism industry rebounds from COVID-19, there must be a push for better, more sustainable actions by larger corporations to take responsibility for their contributions to climate change; actions that go beyond words, that work towards tangible results. Travelers, too, must understand their culpability within the wider system and adjust their consumption accordingly - this does not have to be communicated in a negative light. More localized tourism and slower forms of travel can provide deep and transformative experiences. Finally, policy-makers and governments must shift their willingness to trade short term profits and increased tourism arrivals for long term, biodiverse ecosystems and extended mitigation and adaptation strategies.

\section{Rethinking Tourism Post COVID-19}

There is no question that the tourism industry has been hit hard by COVID-19, however the tourism pause has led to dialogue around how to build a more resilient and sustainable future. Continual economic growth is associated with the biggest challenges humanity faces, all of which are reflected in the tourism industry. Relying solely on economic and arrival numbers is not a true representation of a healthy destination. The quality of the destination, designated by a flourishing society, ecosystem, and economy, must be the primary focus as the tourism industry begins to restart, post COVID-19.

Equity and justice for people and the environment must be brought to the foreground, whereby local residents dealing with the consequences of an inequitable tourism industry are given a voice. Residents, activists, businesses, non-governmental organizations, and political institutions should all have a seat at the table, rather than corporate industry demanding center stage. These stakeholders should view the long-term sustainability of the destination as complementary to the survival of businesses and communities, not as secondary or disconnected. Residents should have access to the resources typically only available to travelers, especially activities where residents are compromising their livelihoods to preserve the assets for international tourists. This collaboration must be marked by a systemic approach to sustainable processes rather than a linear supply and demand, or growth frameworks.

Until a more inclusive and equitable system is created, businesses and travelers should act responsibly and recognize the gravity of their decisions. While 'responsibility' is relative and dependent on the motivations of the person or entity, generally reflecting on how individual actions can impact those beyond the self may be a good place to start. There are benefits that extend past the bottom line and perspectives that are not considered within the greater tourism development space. Emphasizing understanding and empathy for others and the environment could be the best way to re-emerge from COVID-19.

\section{Future of Tourism Coalition}

Prototypes for rethinking tourism post COVID-19 are emerging all over the world. One such example is the Future of Tourism Coalition (FTC). At the beginning of the COVID-19 pandemic, six non-governmental organizations (NGOs), including the Center for Responsible 
Travel, Destination Stewardship Center, Green Destinations, Sustainable Travel International, Tourism Cares, and the Travel Foundation, formed the Future of Tourism Coalition. They crafted thirteen Guiding Principles "to place destination needs at the center of tourism's new future" (FTC, 2020). These principles served as a priori codes for research conducted by Arizona State University (ASU) Center for Sustainable Tourism and the Center for Responsible Travel (CREST), resulting in a co-produced report (ASU-CREST, 2021).

The report produced key insights from an expert panel webinar discussion around climate change and COVID-19. These experts represented the voices of academia, industry, and consumer behavior. Principles 3 (Collaborate in destination management), 4 (Choose quality over quantity), 8 (Mitigate climate impacts), 11 (Diversify source markets), and 13 (Operate business responsibly) were the top six themes discussed in the webinar, as well as an emergent theme of Consumer perspectives and responsibilities. The highlighted themes within the ASU and CREST report shows the need for change within the current tourism industry to address the impacts of climate change and COVID-19.

These most-frequently discussed themes are used in this article to show how the two threats of climate change and COVID-19 are connected to the themes of continual economic growth and sustainability. While the other FTC principles $(1,2,5,6,7,9,10$, and 12) are not discussed in depth within this article, they are important in understanding how the tourism industry is sought to be recalibrated. However, the ASU and CREST report is the single piece of academic literature on the FTC principles, therefore requiring further scholarly research to be conducted on or with the principles before a further discussion on the remaining principles can be penned. Nevertheless, the FTC is influential, given the prominence of its founding organizations and hundreds of signatories worldwide. The FTC principles are also futureoriented and serve as an important, practical complement to the overarching issues presented in the preceding discussion.

Collaborate in destination management, principle 3, was discussed as a way to bring various stakeholders within destinations together for a more diverse, representative decision-making process. It is promising to note that the hundreds of signatories of the FTC Guiding Principles include government agencies and management organizations, businesses, NGOs, academic institutions, and media organization, showing that wider collaboration is becoming more possible. Both climate change and COVID-19 recovery require collaboration between various entities, especially in the tourism industry, where there are often conflicting goals and motivations.

The need to divorce the tourism industry's reliance on arrivals and foreign exports from markers of positive tourism development is described in Choose quality over quantity, principle 4. Economic profit must be viewed as positive only if societal and environmental needs are supported in the process. In other words, tourism developers and managers must "be agnostic about growth" (Raworth, 2017, p. 207). Growth is not always positive or always negative, but the wider narrative must be considered to move beyond linear and continual profit.

Mitigate climate impacts, principle 8 , is an important aspect to address within the tourism industry. Nearly all parts of the expansive tourism system have impacts on climate change. If these impacts are not mitigated, the ramifications will continue to be felt by not only the businesses operating in the tourism space, but by the wider society and environment globally. 
Diversify source markets, principle 11, and the need to Operate business responsibly, principle 13, go hand in hand. Rather than pushing for foreign travelers as the desired client of tourism businesses, operators can engage the domestic market more comprehensively. This strategy may reduce the overall amount of carbon emissions from long-haul flights, but may also allow local residents to enjoy the destinations typically limited to international tourists. For too long, residents in especially the Global South have been left out of the conversation, with tourism perpetuating imperialism. The destination belongs to the people and ecosystem that live and exist within it, not to the corporation that pays enough to change it irrevocably.

Finally, the emergent theme of Consumer perspectives and responsibilities was introduced within the ASU and CREST report as an important factor not explicitly listed within the FTC Guiding Principles. This theme allows for the acknowledgment that travelers are part of the stakeholder network within destinations, and therefore have a responsibility to protect it. The onerous nature of destination stewardship cannot fall squarely on the backs of local residents, institutions, or business, but rather the traveler must accept a similar recognition that their actions have consequences within the destinations.

A better system can be created that more effectively combines social, environmental, economic, and institutional aspects for the long-term sustainability of tourist destinations. This inclusive and equitable agenda should not be linear or top-down, but dynamic, diverse, and co-constructed between the variety of stakeholders: institutions, governments, the private sector, and residents. Collaboration should identify ways in which the benefits and consequences from tourism can be sustainably distributed. Only then will travelers, practitioners, scholars, and policy-makers be able to create a better industry that can address climate change and rebuild from COVID-19.

\section{References}

Arizona State University Center for Sustainable Tourism \& Center for Responsible Travel. (ASU- CREST). (2021, January 15). Results from CREST 2020 World Tourism Day Webinar, 'The Case for Responsible Travel: Lessons from COVID -19 for Tourism in a Changing Climate'. Retrieved from https://scrd.asu.edu/sites/default/files/asu_-_crest_final_report.pdf.

BBC. (2019, May 9). Thailand: Tropical bay from 'The Beach' to close until 2021. BBC. Retrieved from https://www.bbc.com/news/world-asia-48222627.

Center for Responsible Travel (CREST). (2020). The Case for Responsible Travel: Trends \&. Statistics 2020. https://30ghywahyur3pzyoi3qg4r9c-wpengine.netdna-ssl.com/wpcontent/uploads/sites/213/2021/03/trends-and-statistics-2020.pdf

Cheer, J., Ting, H., \& Leong, C. (2021). Responsible Tourism: A New Era of Responsibility? Journal of Responsible Tourism Management, 1(1), 1-17.

Dredge, D. (2019). A policy research agenda for tourism and development. In R. Sharpley. and D. Harrison. (Eds.) A Research Agenda for Tourism and Development (pp.35-52). Cheltenham, UK: Edward Elgar Publishing.

Epler Wood, M. (2017). Sustainable Tourism on a Finite Planet: Environmental, Business and Policy Solutions. Abingdon, OX: RoutledgeFox-Skelly, J. (2017, May 4). There are diseases hidden in ice and they are waking up. $B B C$. Retrieved from 
http://www.bbc.com/earth/story/20170504-there-are-diseases-hidden-in-ice-and-theyare-waking-up.

Future of Tourism Coalition (FTC). (2020). Home. Retrieved from. https://www.futureoftourism.org/guiding-principles.

Higgins-Desbiolles, F., Carnicelli, S., Krolikowski, C., Wijesinghe, G., \& Boluk, K. (2019). Degrowing tourism: rethinking tourism. Journal of Sustainable Tourism, 27(12), 1926-1944. DOI: 10.1080/09669582.2019.1601732

Jones, K., Patel, N., Levy, M., Storeygard, A., Balk, D., Gittleman, J. \& Daszak, P. (2008). Global trends in emerging infectious diseases. Nature, 451, 990-993.

Lew, A. A., Cheer, J. M., Haywood, M., Brouder, P., \& Salazar, N. B. (2020). Visions of travel and tourism after the global COVID-19 transformation of 2020. Tourism Geographies, 22(3), 455-466.

Milano, C., Novelli, M., \& Cheer, J. M. (2019). Overtourism and degrowth: a social movements perspective. Journal of Sustainable Tourism, 27(12), 1857-1875.

Raworth, K. (2017). Doughnut Economics: Seven Ways to Think Like a $21^{\text {st }}$ Century Economist. White River Junction, VT: Chelsea Green Publishing.

Scheyvens, R. (2007). Exploring the Tourism-Poverty Nexus. In Pro-poor Tourism: Who Benefits? In C. M. Hall. (Ed.) Perspectives on Tourism and Poverty Reduction (pp. 121-144). Cleverdon, UK: Channel View Publications.

Schmelzer, M. (2015). The growth paradigm: History, hegemony, and the contested making of economic growthmanship. Ecological Economics, 118, 262-271.

Shakouri, B., Khoshnevis Yazdi, S., \& Ghorchebigi, E. (2017). Does tourism development promote CO2 emissions? Anatolia, 28(3), 444-452.

United Nations Secretary General (UNSG). (2020). Secretary-General's remarks to Petersberg Climate Dialogue. https://www.un.org/sg/en/content/sg/statement/2020-0428/secretary-generals-remarks-petersberg-climatedialogue-delivered.

Vidal, J. (2020, 18 March) 'Tip of the iceberg': Is our destruction of nature responsible for Covid19? The Guardian. Retrieved https://www.theguardian.com/environment/2020/mar/18/tip-of-the-iceberg-is-ourdestruction-of-nature-responsible-for-covid-19-aoe. 